\title{
Reliability and validity of spirituality questionnaire by Parsian and Dunning in the Spanish version ${ }^{1}$
}

\author{
Luz Patricia Díaz Heredia² \\ Alba Idaly Muñoz Sánchez ${ }^{3}$ \\ Divane de Vargas ${ }^{4}$
}

The aim of this methodological study was to translate, culturally adapt and assess the internal consistency and validity of the Spanish version of the "Spirituality Questionnaire". The sample comprised 204 young people between 18 and 25 years of age from two universities in Bogotá. Cronbach's Alpha was used for reliability, while groups of experts and young people were used for construct validity. Exploratory and confirmatory factor analysis was used for construct validity. The reliability score of the total instrument was 0.88 . The overall index of content validity corresponded to 0.90 . Exploratory factor analysis showed that four factors explain $52.60 \%$ of the variance. The originally proposed theoretical model was confirmed and, in two dimensions, a different structure was proposed. In conclusion, the instrument "Spirituality Questionnaire" by Parsian and Dunning is reliable and valid in the Spanish version.

Descriptors: Spirituality; Questionnaires; Validity of Tests; Young Adult.

\footnotetext{
${ }^{1}$ This research was supported by Division de Investigacion de la Sede Bogotá de la Universidad Nacional de Colombia (DIB 11921). Paper extracted from Doctoral Dissertation "Autotrascendencia espiritualidad y bienestar en adultos emergentes universitarios no consumidores y consumidores moderados de alcohol, aportes desde la promoción de la salud" presented to Universidad Nacional de Colombia.

2 MSc, Associate Professor, Universidad Nacional de Colombia, Colombia.

${ }^{3}$ PhD, Assistant Professor, Universidad Nacional de Colombia, Colombia.

${ }^{4}$ PhD, Associate Professor, Escola de Enfermagem, Universidade de São Paulo, Brazil.
} 


\section{Validade e confiabilidade do Questionário de Espiritualidade de Parsian e Dunning em versão espanhola}

Trata-se de estudo metodológico que objetivou traduzir, adaptar culturalmente, avaliar a consistência interna e validade da versão em espanhol do Questionário de Espiritualidade, de Parsian e Dunning. A amostra foi composta por 204 estudantes entre 18 e 25 anos, de duas universidades de Bogotá, Colômbia. Parar testar a confiabilidade utilizou-se o alpha de Cronbach. A validade de conteúdo foi realizada por um grupo de juízes e uma amostra de 12 estudantes. Para validade de construto foram realizadas análises fatoriais exploratória e confirmatória. A confiabilidade total obteve um alfa de 0,88. O índice total de validade de conteúdo observado foi de 0,90 . O produto da análise fatorial evidenciou que $52,6 \%$ da variância foi explicada pelos quatro fatores. O modelo teórico proposto originalmente foi confirmado, observando-se diferença em duas das dimensões originais. Concluiu-se que o instrumento é confiável e válido em sua versão em língua espanhola.

Descritores: Espiritualidade; Questionários; Validade dos Testes; Adulto Jovem.

\section{Confiabilidad y validez del cuestionario de espiritualidad de Parsian y Dunning en versión española}

Se presenta un estudio de tipo metodológico, cuyo objetivo fue el de traducir, adaptar culturalmente, evaluar la consistencia interna y la validez de la versión en español del "Cuestionario de Espiritualidad". La muestra fue de 204 jóvenes de 18 a 25 años, de dos universidades en Bogotá. Se utilizó el Alpha de Cronbach para la confiablidad, mientras la validez de contenido fue por paneles de expertos y jóvenes. Para la validez de constructo se utilizó el análisis factorial exploratorio y confirmatorio. La confiablidad del instrumento total fue de 0.88. El índice global de validez de contenido de 0.90. El análisis factorial exploratorio arrojó que el $52.60 \%$ de la varianza está explicada por cuatro factores. Se confirmó el modelo teórico originalmente propuesto y en dos de las dimensiones se planteó una estructura diferente. Se concluye que el instrumento "Cuestionario de Espiritualidad" de Parsian y Dunning es confiable y válido en su versión en español.

Descriptores: Espiritualidad; Cuestionarios; Validez de las Pruebas; Adulto Joven.

\section{Introduction}

The validation of scales is considered an important part of the development of science and knowledge(1). To support the development of the doctoral dissertation entitled Self-transcendence, Spirituality and Well-Being in Emerging Adult College Students with no or moderate Alcohol Consumption, the reliability and validity of the instrument "Spirituality Questionnaire"(2) had to be determined, which would be part of the set of instruments used in the project and whose psychometric properties had not been determined in Spanish.

Spirituality has been reported in health and nursing literature as an element that contributes to people's mental and physical wellbeing ${ }^{(3-5)}$. Similarly, it has been described as a protective factor against alcohol abuse in the young adult population ${ }^{(6-8)}$. It is important to appoint that, in research, spirituality has been addressed from two perspectives. The first focuses on religion, religiosity and religious practices and commitments. The second approach reconstructs spirituality in a perspective that adopts a broader view of God, including the values and principles that gives meaning and purpose to life(9).

In the later, an instrument is available, developed in Australia, which focuses on the spirituality concept based on the internal identity, the meaning of life and young people's connection with themselves and with a higher power and with the environment( ${ }^{(2)}$. It was constructed 
by two nurses and derived from existing relevant literature and two widely accepted and internationally acknowledge instruments developed in the United States. The instrument includes the following subscales: selfawareness, the importance of spiritual beliefs in life, spiritual practices and spiritual needs.

In its original version in English, content validity determined the removal of three items. The final index of the remaining items ranged between 0.88 and 1 . Users' assessment of face validity reported $90 \%$ of clarity and understanding. Construct validity, measured through factor analysis, reported four factors that explain $62.7 \%$ of variance. Reliability, through internal consistency, corresponds to 0.94. The mean Cronbach's Alpha of the four scales was 0.70 ; the test-retest showed no differences according to the Wilcoxon test after an eightweek interval. The final instrument includes 29 items and uses a four-point Likert scale, ranging from strongly disagree (1), disagree (2), agree (3), strongly agree (4). For the initial validation of the English-language version, a sample of 160 young people was used in Melbourne, Australia.

\section{Aim}

The aim was to translate, culturally adapt and assess the internal consistency and validity of the Spanish version of the "Spirituality Questionnaire".

\section{Method}

This methodological research was aimed at establishing the reliability and validity, besides the translation to Spanish and the cultural adaptation of Parsian and Dunning's Spirituality scale for a population of young adults, guided by the proposal for scale validation in health(10). Reliability was established with the help of Cronbach's Alpha. For content validity, groups of experts and young people were developed to determine Lawshe's modified ratio(11). For construct validity, the exploratory factor analysis technique was used through the extraction of common factors and, for confirmation, structural equations. This research involved a sample of 204 young people, between 18 and 25 years of age, from two private universities in Bogotá, Colombia. Participants were contacted after class, when the primary investigator invited them directly. The same person was responsible for data collection, during the first months of September 2010.

The sample size was established, based on the criterion of at least 200 observations $^{(12)}$. For the sake of confirmatory factor analysis through structural equations, a large sample size is necessary, because this increases the significance of analysis results, by reducing the measurement error and improving adjustment ratios. The age range between 18 and 25 years is related to the period of emerging adulthood, focused on in the doctoral research this methodological study was taken from.

Approval for the study was obtained from the ethics committee at Universidad Nacional de Colombia and from the universities where data were collected. Participants received guarantees of anonymity and the possibility to withdraw from the study when they signed the informed consent term.

The development of the process involved the following phases:

\section{Translation and back-translation process}

To develop this phase, two independent accredited translators translated the instrument from English to Spanish; then, one researcher who mastered both languages revised the final version. Another accredited translator back-translated the instrument to English and, finally, it was forwarded to the authors, who approved this new version.

\section{Face validity}

The face validation of instruments is aimed at establishing the acceptability of the scale in the context it will be applied in. Moreover, it permits determining whether the scale measures what it seems to measure ${ }^{(10)}$, based on subjective assessment by experts and other people with the same characteristics as possible users; and, applying clarity, precision and understanding as criteria, face validity was determined. To establish this validity, two groups were constituted: one containing 3 spirituality experts, including one priest and two nurses; and a group of 12 young adults from two private universities in Bogotá. The young people were contacted through the universities' welfare services and answered the instruments created for validation purposes, individually and in the presence of the primary investigator.

\section{Content validity}

Content validity was analyzed to determine the extent to which an instrument reflects a specific content domain of what is measured. To validate the instrument, two expert nurses in spirituality and scale validation participated, who teach at Universidad Nacional de Colombia, as well as one of the priests of the university chapel. The index was 
determined according to the relevance of the item in the questionnaire. The experts applied the content validation instruments at their workplace, in the presence of the primary investigator.

For content validation purposes, relevant, hardly relevant and not relevant were used as criteria, based on previous studies about whether the necessary skill, knowledge and competences are present in the evaluated items.

\section{Construct validity}

The instrument was applied to nursing, physical therapy and psychology students at two private universities in Bogotá, during the first two weeks of September 2010. Course coordinators were requested permission to apply the instrument and each participant received the informed consent term. Instruments were applied at the end of the classes so as not to interfere in academic activities. Application times ranged between 10 and 20 minutes.

Overall validity refers to the possibility of exact, significant and adequate measures through the application of a test. Construct validity is defined as a process through which empirical evidence is accumulated, with a view to establishing pertinence in the measurement of a concept or theoretical construct, through inferences or interpretations elaborated based on test scores. Construct validity, then, is the unifying concept that joins content and criterion validity considerations in a common framework to prove hypotheses about theoretically relevant relations ${ }^{(10)}$.

With a view to establishing how successful the spirituality questionnaire measures and represents the spirituality construct, exploratory and confirmatory factor analysis was applied to ratify the authors' findings in the validation of the English version of the questionnaire.

\section{Exploratory factor analysis}

To determine existing correlations between the spirituality instrument items and whether they had an underlying structure called spirituality, besides the analysis of whether the common factors or main components could explain the groups or dimensions that constitute the instrument, exploratory factor analysis was used, through the main components method and Varimax rotation, with a view to further data interpretation. Factorial loadings of $\geq 0.35^{(12)}$ were accepted. If an item loaded in two or more factors, it was placed in the factor with the highest factorial loading, i.e. closer to 1 or -1 , and with a mathematical difference of more than 0.01 in the factorial loading when compared with other factors. Initially, the analysis was developed freely and resulted in four main factors: self-conscience, spiritual beliefs, spiritual practices and spiritual needs. Data were processed in SPSS $15^{\circledR}$.

\section{Confirmatory factor analysis}

Confirmatory factor analysis through structural equations is used for scale validation. This is a family of multi-variant statistical models that permit estimating the effect and the relations among multiple variables. Structural equation models derived from the need to make regression models more flexible ${ }^{(13)}$. The main advantage of this type of models is that it permits proposing the type and sense of the relations one expects to find among the different variables in the model, followed by the estimation of the parameters specified by the relations proposed at the theoretical level. Therefore, they are also called confirmatory models, as the fundamental interest is to "confirm", through the analysis of the sample, the relations proposed based on the explanatory theory one decided to use as a reference.

Concerning estimation, structural equation models are based on existing correlations among the variables, cross-sectionally measured in a sample of subjects. Thus, to be able to make estimates, it is sufficient to measure a set of subjects at a given time. Structural equation modeling follows a method that involves different phases: specification, identification, parameter estimation, adjustment assessment, re-specification of the model and interpretation of results. The possibility of one single measure to be able to establish causality levels has made these models particularly attractive. For estimates, AMOS (Analysis of Moment Structures) $18^{\circledR}$ statistical software was used.

\section{Reliability}

Internal consistency refers to the consistency of a measure, that is, whether the scale or the test works similarly in different conditions, depending on the same instrument(12), application time, the person performing the measure, subjects, interaction between these sources and pure random error. One may say that reliability is a measure of the error an instrument can generate when unstable and applied on different occasions. To determine the instrument's internal consistency, Cronbach's alpha was determined and, also, the corrected item-total correlation was assessed. These two psychometric parameters indicate the conceptual adaptation of the scale items. Cronbach's Alpha is the most common method used to measure internal consistency. Expected appropriate levels for this coefficient range from 0.7 to 0.9 (70\% to $90 \%)^{(14)}$. 


\section{Results}

\section{Face validity}

Concerning face validity, $83 \%$ of the young people who participated in this phase $(n=12)$ found the questionnaire clear and precise and $91 \%$ that it was understandable. As for wording, some words were adjusted in eleven of the items, always preserving the orientation and sense of the question. The experts indicated that, in general, the scale was clear, understandable and precise. Regarding the wording, they recommended adjustments in words for nine of the items.

\section{Content validity}

Content validity was based on the three experts' opinion. The content validity ratio (CVR) and the content validity index (CVI) were determined based on their consensus. Considering Lawshe's modified ratio, all items are aceptable, as the validity ratio of each was higher than 0.58. For the spirituality questionnaire, the CVI corresponded to 0.90 .

\section{Construct validity}

For factor analysis purposes, the main components analysis extraction method was used, which was restricted to the four factors the scale authors present, so as to determine whether the configuration of the sample coincides with what the authors of the original scale described and with the conceptual framework described as the base of the instrument ${ }^{(15)}$. First, the Kaiser-MeyerOlkin (KMO) measure of sampling adequacy was applied, resulting in 0.861 . This indicates that the variables measure common factors when the index is superior to 0.7; and Bartlett's sphericity test, which showed statistical significance ( $p 0.000 ; 406 \mathrm{gl}$; Chi 2702.03). This permits the statistical definition that, in this case, the correlation matrix is not an identity matrix and that, hence, factor analysis can be developed.

Next, exploratory factor analysis was developed, showing that four factors are freely found which explain $52.6 \%$ of total variance. As for the factor loading per item, the arrangement of the first factor, called self-awareness, is similar to the original instrument, except for the item "I believe I have the same qualities and shortages as other people", found neither in this factor nor in any other. The alpha for this factor equaled 0.83

The second factor, called spiritual beliefs, comprised the same four items as appointed by the authors of the original scale, with an Alpha coefficient of 0.91 . The third factor, spiritual practices, consisted of the six originally proposed questions. In addition, however, it was observed that some of the questions scored not only in this factor, but also in the second factor about beliefs: items 15 and 20 , related to "I reflect to find internal peace" and "I seek moments to enhance spirituality", which can comprise and be considered as beliefs or as spiritual practices in the Colombian context. Both items were maintained in this factor, as the difference was inferior to 0.01 .

In the fourth factor, Spiritual needs, six of the nine items proposed corresponded to this dimension in the sample. Three items, however, item 21 "I look for beauty in life", item 22 "I try to find answers to the mysteries of life" and item 23 "I try to reach internal peace and harmony" saturated in the spiritual practices factor as well. As the difference was superior to 0.01 , the decision was made to place them in the factor with the highest loading, i.e. in the spiritual needs factor, but mainly because their theoretical contents correspond to what is referred to in the Colombian context as spiritual practices. (Table 1)

With a view to determining the construct validity of the scale and confirm its theoretical structure, and considering that this is the first analysis of the Spanish version, confirmatory factor analysis was executed through Structural Equations and the maximum likelihood parameter, which is the most widely used in general structure equation models. This statistical method permits hypothesizing in the proposed model that spirituality, as a latent variable, is related with and explained by self-awareness, spiritual beliefs, spiritual practices and spiritual needs. This model, proposed based on what the original scale authors indicated, was assessed and developed in AMOS (Analysis of Moment Structures) Graphics software, version 18.0. As no good model adjustment was found based on the items' organization in the dimensions the authors proposed, a new analysis was developed, considering the new structure in the spiritual practices and spiritual needs dimensions, supported by the findings of the Exploratory Factor Analysis. These sustain the spirituality construct measured through the proposed dimensions and including the adjustments in two dimensions: spiritual practices and needs.

The standardized regression weights for each independent variable, which express the extent of each dimension's contribution to the spirituality measure, corresponded to 0.67 for self-awareness influenced by spirituality; 0.57 for spiritual beliefs influenced by spirituality, 0.84 for spiritual practices influenced by spirituality, and 0.45 for spiritual needs influenced by spirituality.

To analyze the proposed model, the global adjustment of the observed data had to be proven, based on a 
Table 1 - Exploratory factor analysis results for spirituality questionnaire

\begin{tabular}{|c|c|c|c|c|}
\hline \multicolumn{5}{|c|}{ Parsian \& Dunning Spirituality Questionnaire - 2008. $(\alpha=0.889)$} \\
\hline & \multicolumn{4}{|c|}{ Components } \\
\hline & 1 & 2 & 3 & 4 \\
\hline \multicolumn{5}{|l|}{ Self-awareness $(\alpha=0.839)$} \\
\hline 05. En general me siento satisfecho con la persona que soy & .815 & & & \\
\hline 03. Siento que tengo muchas cualidades & .640 & & & \\
\hline 04. Tengo una actitud positiva conmigo mismo & .753 & & & \\
\hline 01. Creo que soy una persona valiosa & .698 & & & \\
\hline 07. En general soy una persona que cree en sí misma & .833 & & & \\
\hline 08. Creo que mi vida tiene algún significado & .693 & & & \\
\hline \multicolumn{5}{|l|}{ 02. Creo que tengo las mismas cualidades y defectos que otras personas } \\
\hline 06. Siento que soy una persona compasiva y amable & .407 & & & \\
\hline 09. Soy capaz de entender lo que representan las situaciones difíciles & .567 & & & \\
\hline 10. Pienso en aspectos positivos cuando evalúo mi vida & .630 & & & \\
\hline \multicolumn{5}{|l|}{ Importance of spiritual beliefs $(\alpha=0.914)$} \\
\hline 11. La espiritualidad me ayuda a definir las metas que establezco en mi vida & & .842 & & \\
\hline 12. La espiritualidad me ayuda a decidir quién soy & & .856 & & \\
\hline 13. La espiritualidad me ayuda a decidir mi orientación general en la vida & & .859 & & \\
\hline 14. La espiritualidad está integrada en mi vida & & .857 & & \\
\hline \multicolumn{5}{|l|}{ Prácticas espirituales $(\alpha=0.757)$} \\
\hline 19. A menudo me involucro en programas para cuidad el medio ambiente & & & 670 & \\
\hline 16. Leo libros de crecimiento espiritual y auto-ayuda & & & 621 & \\
\hline 15. Reflexiono para alcanzar la paz interior & & .460 & .499 & \\
\hline 18. Trato de vivir en armonía con la naturaleza & & & .504 & \\
\hline 20. Trato de encontrar momentos para ampliar mi espiritualidad & & .595 & .537 & \\
\hline 17. Empleo el silencio para ponerme en contacto con mi yo interior & & & 641 & \\
\hline \multicolumn{5}{|l|}{ Spiritual needs $(\alpha=0.786)$} \\
\hline 25. Estoy buscando un propósito en la vida & & & & .640 \\
\hline 24. Realmente disfruto escuchar música & & & & .633 \\
\hline 22. Trato de encontrar respuesta a los misterios o dudas de la vida & & & .556 & \\
\hline 28. Mantener y fortalecer las relaciones con los demás es importante para mí & & & & .706 \\
\hline 23. Trato de alcanzar la paz interior y la armonía & & & .587 & \\
\hline 21. Busco la belleza física, espiritual y emocional en la vida & .425 & & .408 & \\
\hline 27. Necesito tener un vínculo emocional fuerte con las personas que me rodean & & & & .715 \\
\hline 26. Mi vida es un proceso de cambio y está en evolución & & & & .561 \\
\hline 29. Estoy desarrollando una visión particular de vida & & & & .434 \\
\hline
\end{tabular}

range of coefficients observed and which reproduce the observed variances and co-variances as good as possible. The absolute chi-square $=5.747$ with $p$-value $=0.057$; the goodness of fit index (GFI), corresponding to 0.998 for the evaluated model, and the root mean square error of approximation (RMSEA) was 0.00 (Table 2).

Table 2 - Adjustment indices of the final model

\begin{tabular}{cccc}
\hline \multicolumn{1}{c}{ Adjustment index } & GFI & AGFI & RMSEA \\
\hline Adjusted model & .998 & .992 & .000 \\
\hline
\end{tabular}

It can be concluded that the hypothesis in the theoretical scale model by relocating the three items (21, 22 and 23) in the spiritual practices dimension adjusts satisfactorily. The description of item 2 was modified and the item was kept in the same dimension where the authors placed it.

\section{Discussion}

Spirituality has been appointed as a core aspect of care since the origins of nursing(16). It is acknowledged as an aspect of strength and an essential part of the dimensions present in each person. It is paramount for the profession to deliver holistic nursing care to this evolutionary and transcendent unique being. Although this objective is directed at qualitative approaches, the construct needs to be measured objectively as well, with a view to establishing care and interventions ${ }^{(17)}$. 
Different instruments have been used to measure spirituality, developed for elder and ill adults(18) and centered on their professed religion(2) instead of their existential perspective ${ }^{(19)}$. The approach of this measure based on the characteristics inherent in the specific period of youth has not been included either, which is why the validation of an instrument that attends to these needs creates the possibility of further research related to this construct in this population group.

In addition, less research has been developed on the measurement of spirituality in young adults, as evidenced in a recent systematic review ${ }^{(20)}$, besides the fact that the validated instrument is relatively new and that studies using it are still limited. As a result of these situations, discussion and contrast with literature are limited.

Spirituality plays an acknowledged role in protecting against some risk situations, like in the case of alcohol abuse $^{(21)}$ and supports mental(22-23) and physical(24) health. This relation poses the challenge for nursing to clarify how and what are the benefits achieved when spirituality is strengthened. These aspects can only be clarified through an appropriate measure of this construct.

The present study findings are coherent with the results the scale authors presented(2). The Cronbach's Alpha coefficient supported the test consistency, as 0.88 is considered an adequate coefficient for an instrument in the initial development phases ${ }^{(14)}$. The face validity test permitted adapting the instrument to the Colombian context and to Spanish; the content and construct validity confirmed that the four dimensions, self-awareness, spiritual practices, spiritual needs and spiritual beliefs, are sufficient and pertinent to measure spirituality in this population group. The confirmation of construct validity through structural equations demonstrated that the latent variable spirituality is related to the previously mentioned dimensions and that the structure of the spiritual practices and spiritual needs dimensions, when items 21,22 and 23 are relocated to the first, in accordance with the exploratory factor analysis, improves the adjustment of the model(2). This result and the use of confirmatory factor analysis through structural equations is important, because it advances on the consolidation of the instrument's psychometric properties and represents a possibility for nursing to include this method in psychometric investigation.

For nurses in general, it is very important to have instruments at their disposal with good psychometric qualities, with a view to measuring complex and important constructs to establish nursing care orientations. As a result of the intangible but undeniable relation between spirituality and health, nursing professionals seek tools like this instrument to acknowledge spirituality as an essential component that is present in young people, independently of their religious belief.

For future psychometric research purposes, the validation of the scale in other languages is proposed, as well as stability assessment through test-retest and the establishment and standardization of cut-off points for this and other populations. For applied research and Latin American nursing, studies are proposed that involve spirituality as a variable in the young population, clearly realizing that, when using the "spirituality questionnaire", it is spirituality that is being measured, and not any other construct. Although this study represents advances for nursing research, there are some limitations, such as the use of a non-random sample, which can be considered a weakness with a view to the generalization of the obtained research results.

\section{Conclusions}

The validation process of Parsian and Dunning's Spirituality questionnaire permitted establishing that the measurement of a complex construct like spirituality in a young adult population is possible with high psychometric quality levels. In conclusion, the "Spirituality questionnaire" is a reliable and valid instrument in its Spanish version.

The researchers recommend the continued application of the instrument in different studies, so as to consolidate the validation process that was started here.

\section{Acknowledgments}

To the authors of the "Spirituality Questionnaire", Drs. Nasry Parsian and Trisha Dunning, for their authorization to use the instrument in the research.

To the Research Division of Universidad Nacional de Colombia - Sede Bogotá, for the financial support received to develop the doctoral dissertation: Self-transcendence, spirituality and well-being in students with moderate or no alcohol consumption: contributions to health promotion, code DIB 11921.

\section{References}

1. Kimberlin $C L$, Winterstein AG. Validity and reliability of measurement instruments used in research. Am J Health Syst Pharm. 2008;65(23):2276-84.

2. Parsian N, Dunning T. Developing and validating a questionnaire to measure spirituality: psychometric process. Glob J Healh Sci. 2009;1(1):2-11.

3. Sánchez B. Dimensión espiritual del cuidado en situaciones de cronicidad y muerte. Aquichan; 2004;4(4):6-9. 
4. Reed P. Spirituality and Mental Health in Older Adults: extant knowledge for nursing. Fam Commun Health. $1991 ; 14(2): 14-25$.

5. Coyle J. Spirituality and health: towards a framework for exploring the relationship between spirituality and health. J Adv Nurs. 2002;37(6):589-97.

6. Wong J, Rew L, Slaikeu K. A Systematic Review of Recent Research On Adolescent Religiosity Spirituality And Mental Health. Issues Mental Health Nurs. 2006;27:161-83.

7. Vondras D, Schmitt R, Marx D. Association between aspects of spiritual well being alcohol use, and related social- cognitions in female college students. J Relig Health. 2007;46(4):500-15.

8. Galanter M. Spirituality and addiction: A research and clinical perspective. Am J Addict. julio-ago 2006;15(4): 286-92.

9. Delaney C. The spirituality scale. JHN. 2005;23(2): 145-67.

10.SánchezR, EcheverryJ.Validación deescalas demedición en salud. Rev Salud Pública. [periódico na Internet]. nov 2004 [acesso 22 abril 2011]; 6(3):302-18. Disponivel em: http://www.scielosp.org/scielo.php?script=sci_ arttext\&pid=S0124-00642004000300006\&Ing=en. doi: 10.1590/S0124-00642004000300006.

11. Tristán A. Modificación al modelo de Lawshe para el dictamen de validez de contenido de un instrumento objetivo. Avances Med. 2008;6(1):37-48.

12. Boomsma A, Hoogland JJ. The robustness of LISREL modeling revisited. En: Cudeck R, Du Toit S, Sörbom D, editors. Structural equation modeling: present and future. A festschrift in honor of Karl Jöreskog. Chicago: Scientific Software International; 2001. p. 139-68.

13. MacCallum RC, Austin JT. Applications of structural equation modeling in psychological research. Annu Rev Psychol. 2000;51:201-26.

14. Gonzalez- Ortega Y. Instrumento Cuidado de Comportamiento profesional: validez y confiabilidad. Aquichan. 2008;8(2):170-82.

15. Parsian N, Dunning T. Spirituality and coping in young adults with diabetes: a cross-sectional study. EDN. 2009;6(3):100-4.

16. Sánchez HB. Bienestar espiritual en personas con y sin discapacidad. Aquichan. 2009;9(9):8-22.

17. McEwen M. Spiritual nursing care. Holist Nurs Pract. 2005;19(4):161-8.

18. Dailey DE, Stewart AL.Psychometric caracteristics of the spiritual perspective scale in pregnant africanamerican woman. Res Nurs Health. 2007;30:61-71.

19. Delaney Collen. The spiritual Scale. J Holistic Nurs. 2005;23(2):145-67.

20. Cotton S, Mc Grady ME, Rosenthal S. Measurement of religiosity/spirituality in adolescent health outcomes research: treands and recommedations. J Relig Health. 2010;49:414-4.

21. Miller WR, Boguenschutz M. Spiritality and addiction. Southern Med J. 2007;100(4):433-5.

22. Gallagher EB, Wasdworth AL, Stratton TD Religion spirituality and mental health. J Nerv Ment Dis. 2002;190(10):697-704.

23. Espíndula JA, Valle ERM, Bello AA. Religion and Spirituality: the Perspective of Health Professionals. Rev. Latino-Am. Enfermagem. [periódico na Internet]. dez 2010 [acesso 4 junho 2011]; 18(6):1229-36. Disponível em: http://www.scielo.br/scielo.php?script=sci_ arttext\&pid=S0104-11692010000600025\&Ing=en. doi: 10.1590/S0104-11692010000600025

24. Swarajyalashmi B. Health and spirituality. An attemp to understand the scope. Indian J Public Health. 2010;54(2):65-70. 